Canadian University Music Review

Canadian University Music Review

Revue de musique des universités canadiennes

--> Voir l'erratum concernant cet article

\title{
Aesthetic Imagination in the Literacy-based Music Classroom: Implications for School Policy and Practice
}

\author{
Carol E. Harris
}

Volume 16, numéro 2, 1996

URI : https://id.erudit.org/iderudit/1014427ar

DOI : https://doi.org/10.7202/1014427ar

Aller au sommaire du numéro

\section{Éditeur(s)}

Canadian University Music Society / Société de musique des universités canadiennes

\section{ISSN}

0710-0353 (imprimé)

2291-2436 (numérique)

Découvrir la revue

Citer cet article

Harris, C. E. (1996). Aesthetic Imagination in the Literacy-based Music Classroom: Implications for School Policy and Practice. Canadian University Music Review / Revue de musique des universités canadiennes, 16(2), 100-115. https://doi.org/10.7202/1014427ar

\section{Résumé de l'article}

Ministry statements regarding music programming tend to be couched either in vague generalities or as conflicting directives for implementation. The aesthetic imagination of students suffers the first loss in school boards that elect to place the responsibility for music in the hands of untrained teachers. This paper traces imagination as emanating from an inextricable combination of impression, sensual perception, ideas, and intentional expression. Imagination itself is examined here first, as heightened perception, and second, as phenomena "becoming." As expression must have substantive material for its realization, music education should include the skills both of performance and of literacy. Anything less denies students, especially the disadvantaged, "voice" and exacerbates the present state of cultural inequality.
All Rights Reserved ( C Canadian University Music Society / Société de musique des universités canadiennes, 1996
Ce document est protégé par la loi sur le droit d'auteur. L'utilisation des services d'Érudit (y compris la reproduction) est assujettie à sa politique d'utilisation que vous pouvez consulter en ligne.

https://apropos.erudit.org/fr/usagers/politique-dutilisation/ 


\title{
AESTHETIC IMAGINATION IN THE LITERACY-BASED MUSIC CLASSROOM: IMPLICATIONS FOR SCHOOL POLICY AND PRACTICE
}

\author{
Carol E. Harris
}

Fundamental to the achievement of a balanced curriculum are quality programs in the arts. ${ }^{1}$

[R] esponsibility for the teaching of arts programs ... rests primarily with the classroom or generalist teacher. Some boards have provided additional support for the classroom teacher through a network of consultants, itinerant teachers, resource teachers, or staff members with additional qualifications or experience.

Ontario Regulation 262 , Section $20, \ldots$ allows a school principal to assign up to two classes in visual arts, music ... to a teacher who does not hold additional qualifications in the particular subject area.

[Music teachers are instructed to:]

* produce and experiment with sounds through a variety of means in order to become increasingly sensitive to rhythm, pitch, dynamics, timbre, form, melody, and harmony; and

* become familiar with and develop the ability to use the language and grammar of music as a means of communication.

The five statements above, emanating from a single Ministry of Education, exemplify common contradictions between the goals of music education and visions of its implementation. Although readers may accept the first accolade to the Arts, those knowledgeable about music will recognize instantly the hurdles facing a generalist teacher untutored in the subject who attempts to engage children in an exploration of the elements of this Art. Yet many school boards continue to assign the teaching of music to those "who do not hold qualifications."

Although the problems inherent in policies that promote the "anyone can teach it" theme are many and complex, I contend that the first loss suffered by children concerns imagination. In music, as in other areas of the curriculum, a

1 These five quotations are found in curriculum guidelines published by the Ontario Ministry of Education. The first quotation is from The Arts in Ontario Schools (1984); the second and third, from the same document, refer respectively to Education in the Primary and Junior Divisions (1975) and Ontario Schools: Intermediate and Senior Divisions (1984); the last two quotations are from the 1975 document. 
child's imagination may find engagement in kinaesthetic, mental, social, and emotional activities. If one or more of these facets of experience are lacking, imaginative engagement is diminished.

What I mean by imagination, and what its significance is for education in general and for music education in particular, is explained in the first part of the present article, after I outline my conceptual position. Next I discuss the nature of imagination, largely through the ideas of R.G. Collingwood. Then I examine aesthetic theories of Eduard Hanslick and others concerning the music listener, composer, and performer as these theories involve imaginative thinking and relate to today's music classroom. My argument supports the thesis that the development of musical imagination and the musical literacy that enables its expression are cruicial considerations for policy-makers who take seriously equality of educational opportunity. From this, I contend that without the goal and realization of literacy, the music program may be a counterproductive component of the school curriculum.

\section{Conceptual Point of Departure}

As Thomas Greenfield and others" remind us, "[o]ur values show in the theories we defend." For this reason, I must identify my assumptions and locate myself in relation to the topic; I am arguing, after all, for the type of music teaching that my experience has led me to value.

My first assumption is that all children, being musically able, should experience as part of their school program the performance and love of music. For children that have this opportunity, we should note appreciable changes between September and June in the manner in which they can sing, move, listen, play, read, improvise, and manipulate the elements of music in writing. These are the skills of musical development that, in my experience, bring a sense of accomplishment to children as they grow in their powers of expression. I am asking no more for music than educators ask for any other area of the curriculum today - that Johnny and Jane become "enabled to solve problems in an unthreatening and supportive atmosphere of exploration." 3 This emphasis on learning and the prerequisites for its accomplishment finds support from curriculum theorist William Doll who holds that

the learner ... needs to know the material studied well enough and have enough personal confidence to be able both to solve, interpret, analyse, and perform the material presented and to play with that material in imaginative and quirky manners. ${ }^{4}$

2Thomas B. Greenfield, "Reflections on Organization Theory and the Truths of Irreconcilable Realities," Educational Administration Quarterly 14, no. 2 (1978): 1-23. Thomas Kuhn, in The Structure of Scientific Revolutions (Chicago: University of Chicago Press, 1962), 16, 17, presents the classic statement of this theme in contending that all researchers bring to their work "some implicit body of intertwined theoretical and methodological belief that permits selection, evaluation, and criticism."

3 William E. Doll, A Post-Modern Perspective on Curriculum (New York: Teachers College Press, 1993), 164.

4 Ibid. 
In a discussion about education, it may appear simplistic to state that a child should learn about the discipline ${ }^{5}$ but I will point out that, in many classroom situations, little musical learning is possible.

My second assumption is that schools fulfil an educative role that is qualitatively different from that of the conservatory. In rejecting the belief that schools inform the masses about music while conservatories prepare individual children in the skills of musicianship, I hold that effective school programs offer unique opportunities in both areas. ${ }^{6} \mathrm{My}$ endorsement of school programs, however, rests on the concept of knowing and doing music as one; we learn about music as we make music. In schools, this joint project which David Elliott calls "musicing" benefits from its social context, a context which allows the range of actions named above.

Although the relative educational value of aesthetic music education and music performance are hotly contended today, ${ }^{8} \mathrm{I}$ wish to dissociate myself from any suggestion that these approaches should be dichotomized in practice. While performance is an essential component of what I mean by aesthetic music education, ${ }^{9}$ my references will be to the host of activities performed within the classroom. The activities of special performance groups I hold to be necessary and beneficial to those involved but, in agreement with Bennett Reimer, as insufficiently comprehensive to be considered all there is to "music education"; they require the support of strong general music programs.

While Canada has never realized a Golden Age of educational opportunity, schools are quickly regressing to the "vertical mosaic" of social structuring noted by John Porter ${ }^{10}$ in the mid-1960s. Faced with calls for school "restructuring" and program accountability, it behooves educators who, after all, have enjoyed a large degree of pedagogical autonomy in their

5The very concept of "discipline" has come under fire of late as theorists advocate an integrated curriculum. While the weakening of subject boundaries is to be commended on many counts, it may have particularly negative repercussions on the Fine Arts. Although the Arts have been used to enhance social studies, language arts, and so on, their utilitarian function has passed, in many cases, for arts education. On this issue, see Noel Gantly, "Integrating the Fine Arts in the Primary Curriculum: Possibilities for Implementation," The B.C. Music Educator (Winter 1992).

6This is not to suggest that conservatories serve a redundant function in music education; rather I see the two institutions as complementary with schools providing basic competencies to all children in a socially interactive environment and conservatories fulfilling an essential service in the refinement of specialized performance skills for those children who can afford the fee.

7 David J. Elliott, "Music As Knowledge," The Journal of Aesthetic Education 25, no. 3 (1991): $21-40$.

8See, for example, Elliott's "Music as Knowledge," ibid., and Bennett Reimer's "Essential and Nonessential Characteristics of Aesthetic Education," The Journal of Aesthetic Education 25, no. 3 (1991): 193-214.

9 Aesthetic music education, in my usage, encompasses far more than it excludes. Apart from musical artistry and its significance in human life, aesthetic concerns deal with "fundamental principles of the interpretation and appreciation of music, the nature and ground of excellence and greatness in music, [and] the relation of music to the rest of the fine arts and to other related practices" (Francis Sparshott, "Aesthetics of Music," in The New Grove Dictionary of Music and Musicians, ed. Stanley Sadie (London: Macmillan, 1980), 1: 120). Applied to music education, I understand aesthetics to involve mind, body, and feelings in the performance of interesting and/or beautiful works of art.

10John Porter, The Vertical Mosaic: An Analysis of Social Class and Power in Canada (Toronto: University of Toronto Press, 1967). 
music programs, ${ }^{11}$ to assess "who is learning what." My third assumption, then, is that policy-makers will do no less.

One final assumption acknowledges the significance of historical review and the value of the "collective memory"12 which develops from the accumulated knowledge of past generations. In the belief that understanding is best approached by combining past wisdom with present insights, I have chosen to embed my argument in the modern tradition while making reference to contemporary school problems. My emphasis on Hanslick and Collingwood ${ }^{13}$ represents a sort of antidote to the deconstructive tendencies of post-modern curricular thought that mount a constant bombardment upon the Western traditional canon of knowledge, subject boundaries, and the very concept of disciplines. While each aspect of such critical thought has its strengths, each, as well, carries its shadow side. In focusing upon substantive music programs that have as their aim the education of the senses, emotions, and powers of expression, I intend to support what Doll calls a "constructively" post-modern view.

\section{Imagination, Its Focus and Significance}

In the language of education, many words appear with a frequency and comprehensiveness that demand definition for each specific usage. Imagination is one such word. This is hardly surprising, for when we speak of imagination, we refer to the mysterious workings of the human mind and body. Difficulties arise in any attempt to mark boundaries clearly between imagination and its components-sensation, perception, image, memory, emotion, idea, intuition, and so on-though such difficulties have not discouraged men and women through the ages from the effort.

Imagination, as used here, has two interrelated foci. The first examines the role of imagination in cultivating sensual perception, of lending to the world what Mary Warnock refers to as "significance." 14 I mean by "cultivating" perception, the incorporation of sensual perception in the activity of evaluation. Such evaluation entails the interpretation of what we perceive before us in the objective world for, although the "facts are before us, we choose our values." Warnock argues that imagination as heightened perception brings to the everyday observation and activity of students a sense of purpose and a consequent release from boredom. The value to education in general of increased meaning

11 See, for example, Ronald Goddard's "Conflicting Perspectives in Music Education," The Canadian Music Educator 35, no. 3 (1994), in which he discusses three main divisions of pedagogical concern-for musical traditions, for the individual student, and for social context. While I disagree with Goddard's forced analysis of these concerns according to prevailing "methods," I appreciate his contribution to our understanding of pedagogical diversification.

12See C.A. Bowers, The Promise of Theory: Education and the Politics of Cultural Change (New York: Teachers College Press, 1987), 22.

13The stance taken by Collingwood concerning the significance of sensual impressions or his presentation of the imaginative process in linear and hierarchical terms, for example, is questioned on many fronts today. I choose Collingwood intentionally, however, for his very insistence on the body-mind unity, his call to educate the emotions, and his treatment of "language." See also footnote 64.

14Mary Warnock, Imagination (Berkeley: University of California Press, 1976), 196. 
and of intentional action is obvious. ${ }^{15}$ In the performance of music-if conducted as an educative exercise-and in its evaluation, students require an ability to recognize, highlight, combine and generally to "play with" the elements of music, in short to "hold alternative conceptions in the mind and assess their adequacy or appropriateness." 16 It is this ability that holds promise of there being more to experience than we can predict, for as Warnock reminds us, without some such sense, "human life becomes perhaps not futile and pointless, but experienced as if it were."17

This brings us to the second sense in which imagination is examined-as an ability to envisage a world "in light of what might be and [yet] what is not." 18 Here imagination demands of teachers and students a critical consciousness whereby they question taken-for-granted assumptions by asking "yes, but" and "what if." 19 In music, such consciousness concerns both content and context. As content, music appears as a particular arrangement of elements that may be varied in a vast array of possible ways. Even very young children may engage in constructing their "language" in ways that are, for them, novel and innovative. The context of music may involve students in questioning the racial, social, and gendered arrangements of their musical culture. Moreover, it may involve envisioning connections between music and other subject areas and bridging even the chasms that seem to exist among the various sub-disciplines of music and genres of performance.

\section{The Nature of Imagination}

In order to develop concepts of imagination as outlined by Collingwood and others, it is necessary to nest imagination within the larger framework of feeling and thinking. All thought and action, according to Collingwood, ${ }^{20}$ are based on feeling. Feeling, itself, is composed of messages from the senses and our emotional responses to sensual stimuli. At this basic level, feelings are involuntary. They are immediate and they occur in the "here and now." According to Collingwood again, sentient and emotional responses are structured in experience so that the former takes precedence over the latter. While Collingwood denies such precedence to be specifically temporal or even causal, he refers to it as an "emotional charge on the corresponding sensation." Although both feeling and response are part of "experience," he contends that we attend far more carefully to our sensations than to our emotions. This seems to be

15Charlene Morton, in "An Aesthetic Panorama of Curriculum: Aesthetics as a Cross-Curricular Dimension of Knowledge" (Paper presented for the Canadian Association of Foundations of Education, Calgary, June 1994), traces aesthetic imagination in subjects apart from the Fine Arts: science, physical education, sex education, and language arts.

16Kieran Egan, Imagination in Teaching and Learning: The Middle School Years (London, Ontario: Althouse, 1992), 42.

17Warnock, 202, 203.

18Maxine Greene, "Breaking Through the Ordinary: The Arts and Future Possibility," Journal of Education, Boston 62, no. 3 (1980): 18-26.

19 Goddard, "Conflicting Perspectives," 24.

20Robin George Collingwood, The Principles of Art (London: Oxford University Press, 1958), 161. 
especially characteristic of adult and "educated" people in ... modem European civilization; among them, it is more developed in men than in women, and less in artists than in others. ... In children this is clearer than in adults, because they have not yet been educated into the conventions of the society into which they have been born. ${ }^{21}$

In other words, Collingwood believes strongly that the conventions of society, perhaps even educational systems, have a numbing effect on the emotional sensitivities of its citizens. I draw attention to this "sterilization of the senses" because of its significance to the imaginative component of music education as discussed later.

In becoming aware of our feelings-be they sensual, emotional, or a combination of the two-we engage in thought. And when we "fix" feelings in time so that they may be contemplated as past or anticipated events, thought becomes imagination. Imagination, thus, becomes the "grounding of feeling" whereby the feelings to which one attends must be somehow stabilized or perpetuated in order to be studied. Such experience ceases to be "mere feeling and enter[s] upon a new stage of its existence." 22 The metaphysician Bergson claims that, for practical purposes, we form solid perceptions and stable conceptions of that which is in reality mobile. We can, in fact, "obtain from [reality] by thought as many stoppages as we desire." ${ }^{23}$ This process of extracting a perception from mobility presents music with an omnipresent challenge. Among the arts, music shares with dance and drama a transitory existence. Any analysis of these arts, therefore, demands continuous acts of imaginative thought.

Collingwood's description of feeling and thinking draw on Hume's notions of impressions and ideas. For Hume, impressions are "those perceptions which enter with most force and violence ... under this name I comprehend all our sensations, passions, and emotions." This emphasis on the force of impressions signifies their involuntary nature whereas, in ideas, Hume sees "the faint images of sensations and emotions in thinking and reasoning." Impressions may be simple-that is, occurring as a single event-or complex. By "complex," Hume refers to impressions received through more than one of the senses at the same time. We have, as well, the ability to rearrange simple impressions into a joined complex for

though no idea can exist even in imagination which was not caused to exist by a previous impression, yet there is a sense in which the imagination is creative ... it can construct what it likes out of the elements at its disposal. ${ }^{24}$

Hume cites memory and imagination as the faculties by which impressions are repeated and presented to ourselves as "ideas." He distinguishes between the two in that "the memory is 'in a manner ty' down' to produce its ideas in the same order as the original impressions were received, whereas imagination has liberty 'to transpose and change its ideas'."25

\footnotetext{
21 Collingwood, Principles, 162.

22 Ibid., 222.

23 Henri Bergson, An Introduction to Metaphysics (New York: Liberal Arts Press, 1955), 51.

24Warnock, 16.

25 Ibid., 15.
} 
Hume's categories of ideas, memory, and that "faculty which transposes and changes ideas" - that is, imagination-are common to the music class. But ideas need to be grounded in experience and, in music, this occurs through the performance of rhythm, melody, harmony, and so on. Through performance, the student begins to perceive and understand the elements of music. Perception and understanding, in turn, enable students to commit patterns of form to memory and to recall and rearrange patterns at will. ${ }^{26}$

Thought described so far is of the first level in Collingwood's hierarchical schema of mental and emotional processes. The focus of such thinking concerns possible or actual relations among sensory impressions and emotions. A second level of thinking involves the intellect where we engage in thoughts about thoughts, "affirming relations between one act of thinking and another or between one thing and another." In Collingwood's schema, however, imagination occurs at the point of contact between the activity of thought and the psychic life of feeling. It is here, as well, in the interweaving of thought and feeling about an artwork, ${ }^{27}$ that the aesthetic experience takes place.

The value of any given work of art to a person properly qualified to appreciate its value is not the delightfulness of the sensuous elements in which as a work of art it actually consists, but the delightfulness of the imaginative experience which those sensuous elements awake in him $\left[\right.$ sic ${ }^{28}$

Clearly Collingwood considers two conditions crucial to aesthetic experience; to be in touch with one's feelings, and to have sufficient knowledge and understanding of the art form to allow for a full flowering of imagination.

Imagination, however, to be fully realized must be expressed. This expression Collingwood calls "language." Language, it must be understood, refers to the spoken or written word or to any medium in which an art work is expressed. For music, language may be translated to mean "sound." We must note, though, that neither the symbolism of notation nor its realization in musical performance is a "language" in the usual sense of the word. As Collingwood points out,

the emotions which we express in music can never be expressed in speech, and vice versa. Music is one order of language and speech is another; each expresses what it does express with absolute clarity and precision; but what they express is two different types of emotion, each proper to itself. ${ }^{29}$.

While emotion may be expressed through music, that emotion cannot be precisely defined. It is specifically musical.

26 We call the instant changing and transposition of musical ideas in performance "improvisation." "Composition," on the other hand, demands reflective design and symbolization.

27For a comprehensive treatment of the relationship between thinking and feeling, see W. Ann Stokes, Intelligence and Feeling: A Philosophical Examination of These Concepts as Interdependent Factors in Musical Experience and Music Education (unpublished doctoral dissertation, Northwestern University, 1990).

28Collingwood, 148.

29 Ibid., 245. 
There is an implicit universalism in Collingwood's conviction that imaginative thought is common to all. We need merely to cultivate our imaginations in order to produce expressively and, if technical skill is present, perhaps creatively. ${ }^{30} \mathrm{He}$ conditions this claim by stating that the deeper the individual's emotional and intellectual experiences, the richer will be the created product. ${ }^{31}$ Moreover, he holds that

[i]magination is a fundamental mode of mind's activity, and the right training of the imagination is therefore a fundamental part of education. ... It means that all education includes ... training of that creative activity which by bringing language into existence reveals thought to itself. ${ }^{32}$

If we, as educators, comply with Collingwood's invitation to provide students with training in imaginative thinking, we must ask this question of each curriculum planner: What is the "right training for the imagination" whereby creative activity may be fostered? Clues as to this training for the young listener, composer, and performer may be found in the aesthetic theories of Eduard Hanslick ${ }^{33}$ and others, the subject of the following section.

\section{Hanslick and the Value of Music}

Critic and aesthetician Eduard Hanslick published his only treatise on music, Vom Musikalisch-Schonen, in 1854. Although he is reputed to be a determined formalist, a closer examination of Hanslick's writing reveals a viewpoint not unlike the expressionism of Collingwood. Hanslick readily acknowledges the "power of music to produce effects upon the feelings," claiming that these effects are "not only more rapid but more immediate and intensive" than those generated by other artistic means; while the other arts persuade, "music invades us." ${ }^{34}$ Hanslick suggests that the emotive power of music derives from audible changes of rhythm, tempo, and dynamics and the ways in which these features correspond with human ideas about audible changes in strength, motion, and proportion such as those of "increasing and diminishing, acceleration and deceleration, clever interweavings, simple progressions, and the like." ${ }^{35}$ These ideas and associated feelings are akin to generalized moods rather than indica-

30Collingwood's explication of the "technical theory of art" deserves far greater consideration than I can give it here. While Collingwood would never support the contention that technique alone provides a sufficient basis for artistry, he concedes that "the better the technique the better will be the work of art" (p. 26).

31 Ibid., 279.

32Ibid., 198.

33 I consider Hanslick's contribution foundational to the work of 20th-century aestheticians of music such as Susanne Langer and Leonard Meyer and to their counterparts in music education such as Bennett Reimer and Abraham Schwadron. See Reimer's The Philosophy of Music Education (Englewood Cliffs: Prentice-Hall, 1971 and 1989) and Schwadron's Aesthetics: Dimensions for Music Education (Washington: MENC, 1967).

34Eduard Hanslick, On the Musically Beautiful, trans. Geoffrey Payzant (Indianapolis: Hackett Publishing, 1986), 50. For a detailed discussion of Hanslick's balanced aesthetic, see Wayne Bowman, "The Value of Musical Formalism," Journal of Aesthetic Education 25, no. 3 (1991): 31-59.

35Ibid., 10. 
tors of specific emotions. While granting that music has the power to arouse emotional response in the listener, Hanslick holds that "specific emotions, such as love, melancholy, or hope exist only within the listener's contextual and historical point of reference." 36

The force and consistency of Hanslick's attack on emotionalism (not to be confused with "expressionism") must be considered in the context of his era. His work is a polemic against the excessive romanticism of the nineteenth century, in which the value of music was commonly held to be in its depiction of specific emotions or in its narrative powers. In contrast, the heart of Hanslick's message is that the beauty of a composition is specifically musical. It depends upon tonal relationships alone and is independent of all alien, extramusical notions. ${ }^{37}$ Although music is an auditory experience and enters our consciousness by way of the senses, its beauty touches us through the manner in which we think about music, that is, through our imagination. ${ }^{38}$

Imagination for Hanslick, as for Collingwood, lies midway between feeling and intellect. It originates with the senses but involves attention and thought. With regard to the aesthetic, "imagining is not mere contemplating, but contemplating with active understanding, i.e., conceiving and judging." 39 .

\section{Theory and Classroom Music}

\section{a. The Listener}

If contemplation arouses pleasurable feelings, this effect depends upon the listener and is distinct from the beautiful as such. This theme is repeated constantly throughout Hanslick's treatise, at times evoking amusing images, such as in this view of enthusiastic listeners who "slouch dozing in their chairs" allowing themselves to

brood and sway in response to the vibrations of tones, instead of contemplating tones attentively. How the music swells louder and louder and dies away, how it jubilates or trembles, they transform into a nondescript state of awareness which they naively consider to be purely intellectual. ... The aesthetical criterion of intellectual pleasure is lost to them; for all they would know, a fine cigar or a piquant delicacy or a warm bath produces the same effect as a symphony..$^{40}$

Even though this diatribe may smack of snobbery to our modern ears, it contains an important message for music teachers. There are many people who fail to recognize aesthetic value, while basking in music's sensuous properties alone. While one gains pleasure from the immediate effects of a driving rhythm, for example, we sell our students short if attention is captured and confined at this level of appreciation.

36Ibid., 9.

37 Ibid., xxiii.

38 Ibid., 4.

39 Ibid.

40 Ibid., 59. 
An analysis ${ }^{41}$ of a composition's main features, prior to hearing the work, permits the student to experience not simply the vague "general aftereffects of feeling, but also the unforgettable, specific image of just this particular piece of music." 42 This specific awareness, Hanslick warns, demands an effort of the intellect. The listener does not merely hear, s/he attends. For imagination is not an isolated domain; "it draws its vital impulse from our sensation and rapidly transmits our sensations to intellect and feeling." 43

The importance of imagination is revealed in Hanslick's description of the aesthetic listener who derives satisfaction from "continuously following and anticipating the composer's designs, here to be confirmed in his expectations, there to be agreeably led astray." This "mental streaming this way and that, this continual give and take, occurs unconsciously and at the speed of lightning." 44 Hanslick further maintains that only when the listener's imagination is engaged in following a composer's musical thoughts may we consider listening an aesthetic experience.

Hanslick leaves us in no doubt as to the significance for him of cognition in the process of aesthetic listening. This is elaborated upon still further in a contemporary context by Aaron Copland who contends that "the intelligent listener must be prepared to increase his awareness of the musical material and what happens to it." 45 Copland extols the listener to hear the melodies, the rhythms, the harmonies, and the tone colours in a conscious fashion. Above all, the listener, in order to follow the composer's thought, must "know something of the principles of musical form." 46 In order to reap maximum benefit from a musical work, Hanslick and Copland direct the listener to become familiar with the formal elements of the music. The sophisticated musician may do so on first hearing a composition; the student, however, must learn how and for what to listen.

\section{b. The Composer}

In many classrooms, the skills of listening are intertwined with those of writing music. In Dewey's terms, children "learn by doing." According to music educator Lois Choksy, the first "compositional" exercises begin when a student has a singing, reading, and writing vocabulary of four or five pitches. The objective here is to vary a simple melodic or rhythmic pattern. Next, students may compose a simple theme and add variations within given limits of meter, measure, rhythm, and pitch. Little by little, teacher-assigned limitations are removed as students take responsibility for formulating their own boundaries. As understanding of musical elements grows, so does the ability to manipulate them in formal compositions; patterns become themes, and themes are re-

41 "Analysis" in literacy-based music programs includes the examination and performance of melodic and rhythmic patterns. See, for example, Lois Choksy, The Kodály Context: Creating an Environment for Musical Learning (Englewood Cliffs, N.J.: Prentice-Hall, 1981).

42Hanslick, 66 .

43 Ibid., 4.

44 Ibid., 64.

45 In Howard Gardner, Frames of Mind (New York: Basic Books, 1985), 103.

46 Ibid. 
peated, contrasted, and varied. ${ }^{47}$ How does this process compare with descriptions of composition by psychologists, composers, and by Hanslick?

Corroborating Roger Sessions' claim by his own extensive research in compositional processes, Howard Gardner finds that the musical image, which lends itself to later development "can be anything from the simplest melodic, rhythmic, or harmonic fragment to something considerably more elaborate." 48 Gardner, this time drawing on the experience of Arnold Schoenberg, notes that an entire composition evolves from a single musical idea which is endlessly shaped and re-shaped. There is, in Schoenberg's words, "nothing in a piece of music but what comes from the theme, springs from it, and can be traced back to it." 49 Thus Schoenberg emphasizes the principles of unity in musical composition. This supports classroom practice as described by Choksy whereby students learn to elaborate upon a basic theme using various compositional modes.

Hanslick describes a similar approach to composing, but adds his notion of expression. He reminds us that rhythm, melody, and harmony are the basic materials from which the composer fashions a musical idea..$^{50}$ The idea itself originates in the imagination as a tonal idea which cannot be expressed in words. ${ }^{51}$ Hanslick adds, however, that it is not feelings that enable one to compose but a specifically musical and technically trained aptitude. According to Hanslick and in agreement with Copland, the object "is to externalize an idea actively emerging in the artist's imagination." 52 The impetus for composition consists of some definite theme or motive and not the desire to describe a given emotion by musical means. Consider for a moment the final movement of Beethoven's Ninth Symphony. The melodic line of the familiar "Ode to Joy" just as appropriately expresses majesty, power, or spiritual transcendence. In other words, although the composer or the listener might attribute a specific emotional message to the music, the music itself does not. It is from the words of the final movement that we determine the specific emotion-joy.

When we consider the quality of Beethoven's life at the time of composition, we realize that, tormented by deafness and debilitating disease, he was far from joyous. His transcendental message is musical in nature rather than discursive. That one may be inspired to joy, at times tantamount to ecstasy, on hearing or performing this line is an aesthetic experience, and the value of music. Although music, for Hanslick, has both meaning and logical sequence, its message is untranslatable; its "realm is truly not of this world." 53

47Choksy, The Kodály Concept, 85-95.

48Gardner, Frames of Mind, 101.

49 Ibid., 102.

50Hanslick, 28.

51 Hanslick speaks of "mind giving shape to itself from within." In returning imagery to imagination, Hanslick declares music a "picture, but one whose subject we cannot grasp in words and subsume under concepts. Music has sense and logic-but musical sense and logic. It is a kind of language which we speak and understand yet cannot translate" (p. 30).

52Ibid., $31,32$.

53Ibid., 30. 


\section{c. The Performer}

Hanslick directs most of his attention to the composer and listener. From his philosophical perspective, a composition, "regardless of whether it is performed or not," is a finished work of art. It is the performer, however, who may contribute the direct outflow of feeling in sound. Here we have "not so much the fabrication of music as [its] reproduction"54; although this reproduction may bear the performer's distinctive stamp. Leonard Meyer, writing a century after Hanslick, adds that performers are challenged to "deviate" slightly from the musical score and from accepted practice. The performer does something unusual in order to express his or her individuality and, in so doing, surprises and delights the audience. According to Meyer, the creative performer considers the score to be a "more or less specific indication ... of what the composer intended and what tradition has established." 55

In this comparison of performer and composer, we find two ideas relevant to the music classroom. In the first, Hanslick defines the composer's work as slow and intermittent with the intention of "lasting for all time," while that of the performer is but the fruition of the moment. Performance is a transitory happening, a segment of "impetuous flight." Students who perform constantly-whether it be class exercises, personal compositions, or selections for large audiences-requite an awareness of this temporal experience. Performance of any kind demands preparation, concentration, and a "giving of one's all" for the opportunity to perform a specific work may not come twice."

Hanslick's second point, as well, concerns the contrasting processes of composition and performance. While composition reveals the working out of a specific musical idea, performance invests the idea with life. It falls to the performer to reveal both the spirit of the music and his or her interpretation. I use the word "interpretation" advisedly for I believe that Hanslick, at one point, oversteps his own boundaries regarding emotion in music by stating that the player has the privilege of venting directly through his instrument the "feeling which possesses him" and to "breathe into his performance the wild storms, the passionate fervour, the serene power and joy of his inwardness." 56 Surely, however, the emotions expressed in performance are not those which at the time hold the performer in sway. They are, rather, emotions that transcend one's personal emotions of sorrow, joy, and the like. They are part of the performer's experiential pool and may be recalled directly or as an amalgam of past experience..$^{57}$ For example, singers must utilize through memory and imagination numerous specific emotions, as demanded by text, during the dramatic moments of a single performance.

In instrumental music, purely musical expression is conveyed by the performer's use of tension and release, dynamics, phrasing, and tempi modifi-

54Ibid., 48, my emphasis.

55Leonard Meyer, Emotion and Meaning (Chicago: University of Chicago Press, 1956), 199.

56Hanslick, 49.

57 "Emotions," of course, may be based either on direct or vicarious experience. Even though a reader has never experienced the death of a loved one, for example, reading of such a loss may elicit an empathetic response that becomes thereafter part of that individual's experiential pool. 
cations. Beauty - or meaning-reside in the musical line itself. Although similar expressive devices are employed in vocal music, here the words as well lend meaning. Mozart reminds us, however, that "good music is forgiving to the most wretched text" 58 although the converse can rarely be the case. It is the perception of music, through the "sense of hearing," that appeals directly to our imagination and our emotional faculty with a force that temporarily transcends that of poetry. .99

Hanslick illustrates this independence of good music from specific linguistic meaning by reversing the message of Gluck's famous aria in which Orfeo sings of his lost Eurydice. According to Hanslick, "I have found my Eurydice" would be as appropriate to the musical line.$^{60}$ Primary music teachers, in particular, employ variants of this experiment in encouraging children to "make up" new lyrics for familiar songs and in demonstrating the independence of music from lyrics. Some choral teachers, moreover, accomplish the latter goal by preparing entire songs in tonic sol-fa, or to a neutral vowel sound, before introducing words. The objective here-in addition to the formal learning of rhythm, melody, and harmony-is the realization of musical "wholeness" before words are added.

\section{Discussion}

With a focus upon imaginative musical thought, we have seen a few examples of how the listener, performer, and "composer" benefits from engagement with the elements of music. In this discussion, of course, many complexities of musical imagination have been passed over. Music, for example, involves participants in "imaginary experiences which do not belong to the region of sound at all, notably visual and motor experience." 61 Thus, imagery as a component of the teaching/learning process provides one area worthy of much closer examination. Metaphor and imagery are employed widely by teachers as they seek to engage children affectively in music and by children in their response to music. Imagery extends to the "motor experience" of school music, as well, where children build upon their repertoire of dance steps, their experience of beat and rhythm, and their knowledge of folk songs to devise novel dances. ${ }^{62}$ Although music education encompasses more than its formal aspects, our success as educators largely hinges on how we incorporate the

58 Ibid., 23.

$59 \mathrm{See}$, as well, Hanslick's reference to Grillparzer concerning the inherent conflict between musical and poetic meaning, pp. 25, 26. Susanne Langer, in Philosophy in a New Key (Cambridge: Harvard University Press, 1957), suggests that this occurs as poetic form within a song is broken up and its "words, sound, and sense alike, its phrases, its images, all become musical material. ... the poem, as a poem, has disappeared in the song" (p. 84).

60 Hanslick, 17. Hanslick's argument, I must add, does not hold up in all cases. Many art songs blend words and music in "organic unity." The unity of German Lieder, for example, arises from the perfect intermingling of music with poetic text.

61 Collingwood, 147. For an extensive treatment of referentialism in music, see L. Ferrara, Referential Meaning in Music: A Conceptual Model Based on the Philosophy of Martin Heidegger (doctoral dissertation in the School of Education, New York University, 1978).

62 See David Brummitt and Lois Choksy, 136 Songs and Dances for Elementary Grades (Englewood Cliffs: Prentice-Hall, 1989), 193-205. For those aware of the seemingly inexhaustible variety of playground games and dances, this may well appear to be a case of the school catching up with reality. 
values of formalism in instruction. As Palmer maintains, "unless we focus on the basic materials of music, we are remiss in bringing to full flower the art of music." ${ }^{63}$ While all children have ideas and emotions worthy of expression, such expression demands an understanding of music and the technical skill to communicate that understanding in "language."

To review the link between what is to be communicated-that is, imaginative content-and language, we note several steps. First, as a foundation for imagination, sensual impressions prompt involuntary response. This response, as feeling or emotion, leads to thoughts about sensual impressions-in the case of music, about tonally patterned sound. Thinking becomes memory or imagination as certain aspects of sensual experience are attended to, grounded, rearranged, and anticipated. As experience is attended to and grounded as a past event, we have memory; as it is rearranged and anticipated, we have imagination. ${ }^{64}$ Kieran Egan reminds us of the dependence of imagination upon memory for the richness, variety, unusualness, and effectiveness of the former rests "in significant degree on how much it has to ... construct with." 65 Or, as Collingwood points out, we imagine only within the boundaries of which we have the language of expression. We do not construct "out of nothing but [from] the tools at our disposal." 66

Hanslick's contention of what it is that we communicate in music seems, at first glance, to contradict Collingwood. Hanslick proposes that musical ideas are communicated; he rejects the suggestion that specific emotions are the stuff of communication. Collingwood, on the other hand, speaks repeatedly of emotions. In looking more closely, however, we see these positions merge. Both theorists recognize that strong feelings flow from sensual perception of music's elements, that feeling must be translated through attention into ideas and that ideas, to be communicated, must be expressed in intentional language. That Hanslick and Collingwood emphasize different threads of intent-the one idea and the other emotion-may be understood in the context of their work. Hanslick, as pointed out above, inhabited a musical world of excessive emotivism while Collingwood perceived his world to be overly concerned with rationality and, as a consequence, emotionally sterile.

Richard Rorty, the contemporary philosopher, introduces the perennial question of whether we should see the medium of language primarily as one of expression at all, of articulating what lies deep within the self, or whether we should see it as primarily a medium of representation-showing the self what lies outside. ${ }^{67}$ Collingwood would extend the role of language to express

63 A.J. Palmer, "Responise to Wayne Bowman," Philosophy of Music Education Newsletter 4, no. 3 (1992): 2.

641 urge readers who find the linearity of Collingwood's explication problematic to consider his work an analytic model. Imagination, as played out in each person's experience, remains a matter of empirical investigation. Whether feeling precedes or follows thought seems to me to be a moot point. The important consideration is of the inextricable links among many factors-impression, perception, affect, cognition, and so on (see Collingwood, 307).

65Egan, Imagination, 52, 53.

66Collingwood, 291.

67Richard Rorty, Contingency, Irony, and Solidarity (Cambridge: Cambridge University Press, 
both the exterior world and the self to the self. When this imaginative task is done well, we see artistry; when it is done superlatively well, we see great artistry. ${ }^{68}$

\section{Conclusion}

Although few school systems aspire to produce full-fledged artists, almost all claim to develop abilities or "talents" 69 in the Fine Arts. Collingwood gives us our first clue as to where artistic ability or talent may be found. This is in the act of imagining which "is the act of uttering language. ... [Expression is] not an embroidering of pre-existent thought; it is the birth of thought itself."70

The writings of Hanslick, and the testimony of composers and educators, clearly indicate the nature of musical "language." Its expression is not in words about music but in music itself. ${ }^{71}$ Musical expression and understanding arise from an ability to manipulate, contemplate, and perform the elements of music in patterns of musical form. There is, moreover, a social dimension to artistic expression for those who have something to say, crave to say it publicly and feel that, until it has been declared, it has not been "said" at all. ${ }^{72}$ Music in schools, though, to be considered an empowering language for students must extend beyond its group-expression in performance halls to individual competencies in both its tonal and symbolic form. Herein for many lies the value of music, and of music education.

If we wish our schools to reflect this valued stance, an examination of Board policies is in order. Policies, after all, reflect the values of their creators. Curriculum designers and policy implementors may step gingerly through the contradictions inherent in Ministry documents to select those directives that support their current practices and priorities. A school system, for example, that acknowledges the nature of the subject will enhance the musical development of its children through supporting teachers that are able to lead others in the communicative skills of music. On the other hand, a school board that offers programs which fail to include an exploration of music's elements and that

1989), 11.

68Collingwood, Imagination, 195.

69David J. Elliott, in "Finding a Place for Music in the Curriculum," Canadian Music Educator 28, no. 2 (1986), points out that, unfortunately, most of the public view "the talented ... as extraordinary children rather than ordinary children doing extraordinary things in virtue of optimal conditions." Research findings substantiate the contention that talent is widely dispersed among children. See Katalin Forrai, "The Cultural Impact of the Kodály Presentation in Early Childhood Education," Bulletin of the International Kodály Society 2 (1983): 18-20; Edwin Gordon, The Psychology of Music Teaching (Englewood Cliffs: Prentice-Hall); Carol E. Harris, "Post-Positivistic Thought: Implications for Naturalistic Research Methods in School Music," Canadian University Music Review no. 12/1 (1992): 52-74.

70 Collingwood, 196.

71 This article's opening quotations are taken from documents affecting present school practice. More recent guidelines, while articulating the role music studies may play in clarifying current social and political issues, unfortunately make little substantive reference to objectives regarding the content of music. Though claiming to be "outcomes-based," one guide for example states that, "no later than grade 9," students are to understand the concepts of "high and low pitch." See Ontario Ministry, Music: Intermediate and Senior Divisions (1990): 27; see also The Common Curriculum, Grades 1-9 (1993).

72 See Collingwood, Chapter XIV, "The Artist and the Community." 
places "responsibility for the teaching of the Arts" in the hands of untrained teachers, ${ }^{73}$ risks doing a great disservice to both its children and to music. Although all children in such boards shoulder these risks, the risks are more pronounced for socially and economically disadvantaged children. School programs may offer children the sole means for developing their musical imagination and "voice."

Zoltán Kodály - the renowned Hungarian composer, conductor, ethnomusicologist, and educator-maintains that the quality of a village teacher has greater long-term significance on the development of a nation's people than does that of the director of the national opera. Although "a poor director will fail, a poor teacher may kill the love of music for thirty years in thirty classes of pupils." 74 In quoting this, I am not suggesting that music is more susceptible to poor teaching than are other subjects; the danger, I believe, is universal. I suggest, however, that policy-makers who adopt laissez-faire attitudes towards the implementation of music programs, face the danger that those invested with the responsibility for teaching music may not have the necessary background to foster learnings that "free the imagination and permit exploration and discovery on a personal level." 75

\begin{abstract}
Ministry statements regarding music programming tend to be couched either in vague generalities or as conflicting directives for implementation. The aesthetic imagination of students suffers the first loss in school boards that elect to place the responsibility for music in the hands of untrained teachers. This paper traces imagination as emanating from an inextricable combination of impression, sensual perception, ideas, and intentional expression. Imagination itself is examined here first, as heightened perception, and second, as phenomena "becoming." As expression must have substantive material for its realization, music education should include the skills both of performance and of literacy. Anything less denies students, especially the disadvantaged, "voice" and exacerbates the present state of cultural inequality.
\end{abstract}

730n this issue, see Hannah Arendt, Between Past and Future: Eight Exercises in Political Thought (Middlesex: Penguin Books, 1968), 184.

74Zoltán Kodály, The Selected Works of Zoltán Kodály (Toronto: Boosey and Hawkes, 1974), 124.

75The Arts in Ontario Schools, Ontario Ministry of Education (1984). 